\title{
Sapanca Gölü (Sakarya) Havzası Toprak ve Sedimentlerinden Streptomyces Cinsi Bakterilerin İzolasyonu, Karakterizasyonu ve Teşhisi
}

\author{
Dilara Hande ÜNAL ${ }^{1}$, Kerem ÖZDEMIR ${ }^{2 *}$ \\ ${ }^{1}$ Van Yüzüncü Yll Üniversitesi, Fen Fakültesi, Moleküler Biyoloji ve Genetik Bölümü, Van \\ ${ }^{2}$ Bandırma On Yedi Eylül Üniversitesi, Mühendislik ve Doğa Bilimleri Fakültesi, Bandırma, Balıkesir
}

\begin{abstract}
$\ddot{O} \mathbf{z}$
Bu çalışmada, Sakarya ili sınırlarında bulunan Sapanca Gölü havzası toprak ve sedimentlerinden Streptomyces cinsi bakterileri izole edilerek karakterizasyon ve teşhisi yapılmıştır. Toplam 6 farklı lokaliteden alınan 12 toprak numunesinin fiziko-kimyasal analizleri yapılmış ve $\mathrm{pH}$ 'larının 6,12 ile 7,58 değerleri arasında olduğu saptanmıştır. Saflaştırılan 60 Streptomyces izolatı havasal, misel ve difüziye pigment rengi esas alınarak 4 ana gruba ayrılmıştır. Streptomyces izolatlarına, antibiyotik duyarlılığı, degredasyon aktivitesi, büyüme, azot ve karbon kaynağı kullanımı testleri uygulanmıştır. Tüm izolatların fenotipik ve biyokimyasal karakterleri belirlenerek IDENTAX bilgisayar programına bu veriler aktarılmış, cins içerisindeki pozisyonları belirlenerek teşhisleri yapılmıştır. Teşhis edilenler türler arasında Streptomyces cyaneus, Streptomyces filipinensis, Streptomyces exfoliatus, Streptomyces chromogenus, Streptomyces chromofuscus, Streptomyces griseoruber, Streptomyces antibioticus, Streptomyces lydicus, Streptomyces lavendulae ve Streptomyces purpureus türleri bulunmaktadır. Teşhisleri tamamlanan Streptomyces izolatlarının test sonuçları MVSP 3.2 bilgisayar programı ile birbirleri arasındaki benzerlik dendogramları oluşturulmuştur. Renk kümelerini temsilen seçilen 4 suşun DNA izolasyon ve dizi analizleri yapılmış ve 27F ile 1492R evrensel primerleri kullanılarak 16S rDNA geni kısmi olarak PCR ile çoğaltılmıştır. $\mathrm{Bu}$ dört bakterinin GenBank veri tabanındaki türlerle olan akrabalık dereceleri ve genetik pozisyonları dendogramlar şeklinde ortaya konmuştur.
\end{abstract}

Anahtar kelimeler: Streptomyces, 16S rDNA, Sapanca Gölü.

\section{Isolation, Molecular Characterization and Identification of Bacteria the Genus Streptomyces from Basin Sedimentary Soil of Sapanca Lake (Sakarya)}

\begin{abstract}
In this study, Streptomyces bacteria were characterized and identified after being isolated from the soil and sediments of Lake Sapanca in Sakarya province. Physico-chemical analyzes of 12 soil samples taken from 6 different localities on total, were carried out. It was determined that the $\mathrm{pH}$ values of the soil samples were between 6.12 and 7.58. The purified 60 Streptomyces isolates were divided into 4 main groups based on air, micelle and diffuse pigment colour. Streptomyces isolates were analysed and tested for antibiotic susceptibility, degradation activity, growth, nitrogen and carbon source use. Phenotypic and biochemical characteristics of all isolates were determined and these data were transferred to IDENTAX computer program and their positions were identified and diagnosed. Species identified include Streptomyces cyaneus, Streptomyces filipinensis, Streptomyces exfoliatus, Streptomyces chromogenus, Streptomyces chromofuscus, Streptomyces griseoruber, Streptomyces antibioticus, Streptomyces lydicus, Streptomyces lavendulae ve Streptomyces purpureus. The test results of the Streptomyces isolates, which have been diagnosed, were compared with the MVSP 3.2 computer program to establish similarity dendograms. DNA isolation and sequence analysis of 4 selected colonies were performed and $27 \mathrm{~F}$ and 1492R universal primers were used to amplify the $16 \mathrm{~S}$ rDNA gene partially by PCR. The genesis and genetic positions of these four bacteria with the species in the GenBank database are presented as dendograms.
\end{abstract}

Keywords: Streptomyces, 16S rDNA, Lake Sapanca.

*Sorumlu yazar: keremozdemir@bandirma.edu.tr

Geliş Tarihi: 14.03.2019, Kabul Tarihi: 30.07 .2019 


\section{Giriş}

1928 y1lında Alexander Flaming'in ilk doğal antibiyotik olan penisilini keşfi ile Streptomyces çalş̧an bilim insanları bu bakterilerde doğal sekonder metabolit arayışına hızlı bir giriş yapmışlardır. Streptomyces bakterilerinin doğal sekonder metabolitleri üzerine çalışmalar, Waksman ve öğrencisi Albert Schatz'in Mycobacterium tuberculosis'e karşı ilk etkili antibiyotik olan Streptomyces griseus'un bir ürünü; streptomycin'i keşfetmesi ile hız kazanmıştır [1]. Bu keşifle beraber 1950 ve 1960'lı yıllarda çok sayıda antibakteriyal ve antifungal antibiyotikler bulunmuş ve bu dönem antibiyotik keşiflerinin Altın Çağ'1 olarak adlandırılmıştır [2,3]. Bu doğrultuda Streptomyces türlerinin üretmiş oldukları biyoteknolojik açıdan önemli primer ve sekonder metabolitlerden dolayı son 40 yıl içerisinde dünya çapında daha geniş çalışmalar yapılmıştır [4].

Streptomyces türleri Gram-pozitif, aerobik, katalaz pozitif, asit-fast olmayan, G+C oranı $\% 69$ 78 arasında değişen ve yaşam döngüleri süresince morfolojik farklılaşma gösteren bakterilerdir. Streptomyces türleri çoğu bakteri türünde görülmeyen miselyumlardan oluşmaktadırlar. Uygun şartlarda toprakta bulunan dinlenme halindeki sporları, henüz bilinmeyen bir sinyal yoluyla vejetatif ve sonrasında havasal miselyumları oluşturur [5]. Çoğunlukla Streptomyces türleri topraktan izole edilmelerine rağmen hem sucul hem de karasal habitatlarda oldukça geniş dağılım gösterirler [6,7]. İzolatların dünyanın birçok farklı bölgesinden izole edilmeleri bu durumu açıklamaktadır. Streptomyces bakterileri toprakta saprofit olarak yaşarlar ve bitki ve hayvan kısımlarının ayrıştırılmasında önemli bir role sahiptirler. Çoğunlukla da kitin, polisakkarit, protein, aromatik bileşenler ve lignoselülozu içeren tortuların degradasyonundan sorumlu ekstraselüler enzimler üretirler. Streptomyces türleri bir lignoselüloz bileşiğindeki selüloz ve hemiselüloz ile birlikte doğada bulunan lignini ayrıştırabilir. Bundan dolayı besinlerin döngüsüne ve dönüştürülmesine katkı sağlamaktadırlar [7]. Ayrıca birçok türü toprak fungusunu parçalar ya da inhibe eder.

Streptomyces türleri actinomisetler arasında ekonomik açıdan önemli bir gruptur. Çünkü sekonder metabolit üreticilerin başında gelirler. 23000'den fazla bilinen mikrobiyal sekonder metabolitin \%42'si Aktinobakterler, \%42'si funguslar ve \%16's1 diğer bakteriler tarafindan üretilir. Günümüze kadar bilinen antibiyotiklerin yaklaşık üçte ikisi Aktinobakteriler tarafindan, bunların da yaklaşı \% \% 75'i Streptomyces bakterileri tarafindan üretilir [8]. Ayrıca Streptomyces türlerinin ürettiği diğer değerli metabolitler; immunosupressif (bağışıklık baskılayıcı), pestisit, antifungal, antiviral, antioksidan, antitümoral, antiparazitik, antihipertansif (kan basıncını düşüren) ve antikanser ilaçlarını kapsar. Bu kapasitelerinden dolayı Streptomyces bakterileri prokaryotlar arasında ayrı bir öneme sahiptir.

\section{Materyal ve Metot}

$\mathrm{Bu}$ araştırmanın materyalini; Sapanca Gölü (Sakarya) çevresinden toplanan sediment örnekleri oluşmaktadır.

\subsection{Toprak örneklerinden Streptomyces bakterilerinin izolasyonu ve saflaştırılması}

Toplanan sediment örneklerinin ilk olarak pH ölçüşdü ve nem tespitleri yapılmıştır. Streptomyces bakterilerin izolasyonu için M65 ve SM3 besi yeri hazırland.. 1/10'luk ve 1/10.000'lik seyreltmelerden M65 ve SM3 plakların yüzeyine $100 \mu 1$ ilave edilerek iyice yayıldı. Petri kapları $27^{\circ} \mathrm{C}$ 'de 7 gün inkübasyona birakıldı. İnkübasyonu müteakip üreyerek havasal misel ve substrat miseli oluşturan koloniler, muhtemel Streptomyces bakteri kolonileri olarak değerlendirildi. M65 ve SM3 besiyerinde gelişen karışık kültürden streril Bennets agar besiyerlerine öze yardımıyla çizgi plak yöntemi ile ekimler yapılarak saf kültürler elde edildi. Saf kültürler \% 20'lik gliserol içeren kriyojenik tüplere aktarılıp derin dondurucuda muhafaza edildi. Tüm izolatların teşhisi için renk gruplandırılması tamlanarak substrat ve havasal misel renkleri belirlendi. Saflaştırılan suşların renk gruplandırması için oatmeal agar (ISP 3) [9]; besiyerine çizgi ekim metoduyla ekim yapıldı. İzolatlar 14 gün $28^{\circ} \mathrm{C}$ 'de inkübe edildikten sonra havasal miselyum rengi ve substrat milselyum renkleri renk kataloğuna göre tespit edildi ve gruplandırma yapıldı. 


\subsection{Potansiyel Streptomyces suşlarının karakterizasyonu ve teşhisi}

60 potansiyel Streptomyces izolat1 Uluslararas1 Streptomyces Projesi tarafindan verilen talimatlara uyarak karakterize edildi [9-11]. Makro-morfolojik, mikro-morfolojik, fizyolojik ve biyokimyasallar ile kemotaksonomik özellikleri belirlendi. Fizyolojik ve biyokimyasal testler tuz tolerans1, karbon kullanımı, azot kaynakları, melanin sentezi, degredasyon testleri, antibiyogram, gelişim testlerini içermiştir [12].

Test organizmaları Williams ve arkadaşları tarafindan belirtilen major Streptomyces grupları için tespit edilen teşhis matrikslerine göre teşhis edildi [7]. Bilgisayar yardımıyla teşhis için IDENTAX Bacterial Identifier 1.2 programı kullanıldı. Seçilmiş olan 60 Streptomyces test suşu için yapılan 61 farklı test sonuçlarının MVSP 3.2 (Multi-Variate Statistical Package) programında $\mathrm{S}_{\mathrm{SM}}$ (Simple Matching Coefficient) konfisiyentlerine göre UPGMA (Unweighted Pair Group Method with Arithmetic Average Cluster) analizleri yapıldı ve dendogram oluşturuldu. Spor zincir morfolojisi elektron mikroskobu (SEM) ile belirlendi.

\subsection{Genomik DNA'nın izolasyonu ve saflaştırılması}

Çalışmada renk gruplandırması ve nümerik analiz sonucu elde edilen dendogram gruplarına göre toplam 4 test organizması seçilerek, her bir suşun tek bir kolonisi alınd1 7 gün boyunca $28{ }^{\circ} \mathrm{C}$ 'de M65 agar besiyerinde geliştirildi. İzole edilen bakterilerden genomik DNA izolasyonu için Ausubel ve arkdaşlarının metodu modifiye edilerek kullanıldı [13].

\subsection{S rDNA geninin Polimeraz Zincir Reaksiyonu (PCR) ile çoğaltılması}

Bakterilerin bütün hücre DNA'sı izole edildikten sonra 27F ve 1492R evrensel primerleri kullanılarak 16S rDNA gen bölgesi amplifiye edildi [14]. PCR programı başlangıç 95C'de $5 \mathrm{dk}, 35$ döngü, denatürasyon için $95^{\circ} \mathrm{C}^{\prime} \mathrm{de} 1 \mathrm{dk}$, anneling $55^{\circ} \mathrm{C}^{\prime} \mathrm{de} 1 \mathrm{dk}$, uzama için $72^{\circ} \mathrm{C}^{\prime} \mathrm{de} 1 \mathrm{dk}$ ve son olarak $72^{\circ} \mathrm{C}^{\prime} \mathrm{de}$ $10 \mathrm{dk}$ olarak ayarlandı. PCR'da çoğaltılmış $16 \mathrm{~S}$ rDNA'ları \% 1'lik $0.5 \mu \mathrm{g} / \mathrm{ml}$ ethidium bromide içeren agaroj jelde (0.5 X TBE tampon) koşturuldu. Yaklaşık $5 \mu 1$ PCR ürünü jel yükleme boyası ile birlikte karıştırılarak jele yüklendi ve 100 voltta 1 saat boyunca koşturuldu [15]. Temsilci test organizmalarının 16S rDNA amplifikasyon ürünleri saflaştırıldıktan sonra hedef bölgenin baz dizilimi ABI PRISM Genetic Analyzer otomatik sekanslama cihazı kullanılarak elde edildi.

\subsection{Sekans benzerlikleri ve filogenetik analiz}

NCBI/GenBank data bank aracılığıyla Streptomyces 16S rDNA nükleotid baz dizileri Mega7 programı kullanılarak hem veri tabanındaki yakın türlerle hem de kendi aralarında analiz edildi. Tüm izolatların $16 \mathrm{~S}$ rDNA nükleotid baz dizileri filogenetik dendogramların oluşturulması için kullanıldı. İzolatların baz dizileri NCBI gen bankasına kaydedildi ve giriş numaraları (accession number) alındı. Mega7 programı ile neighbour-joining metodu kullanılarak türlerin sekans yapılan gen bölgelerine göre filogenetik pozisyonları ve benzerlik oranları belirlendi. Türlere en yakın en az üç takson ile benzerlik oranları tablo olarak sunuldu ve son olarak türlerin akrabalık durumlarının şematize edildiği dendogramlar oluşturuldu.

\section{Bulgular ve Tartışma}

Sakarya-Sapanca Gölü ve çevresinden alınan 12 toprak numunesinin izolasyon öncesinde ölçülen pH değerleri 6,12 ile 7,58 arasında değişiklik gösterdi. Bennett's Agar besi ortamında saflaştırılan toplam 60 Streptomyces suşu Oatmeal Agar besi ortamında ekim sonucu test izolatları 4 renk grubuna ayrıldı. Renk gruplandirması substrat, havasal miselyum ve difüziye pigment rengi dikkate alınarak yapıldı. Oluşan 4 renk grubu sırasıyla 29 (beyaz), 7 (sarı), 22 (gri) ve 2 (krem) test organizması içerdi.

Bilgisayar yardımıyla teşhis için IDENTAX Bacterial Identifier 1.2 programı kullanıldı. Bu program yardımıyla test suşlarının major taksonlar için oluşturulan matrikse göre teşhisleri yapıldı. Sonuçta 60 Streptomyces suşundan 20 tanesi \%85'in altında benzerlik gösterdi. Seçilmiş olan 60 Streptomyces test suşu için yapılan 61 farklı test sonuçlarının MVSP 3.2 (Multi-Variate Statistical 
Package) programında SSM konfisiyentlerine göre UPGMA (Unweighted Pair Group Method with Arithmetic Average Cluster) analizleri yapıldı. SSM-UPGMA (Simple Matching Coefficient) konfisiyent analizlerine göre seçilen mikroorganizmaların dendogramı oluşturuldu. Dendogram \%85 benzerlik oranına göre toplam 3 küme oluşturdu. Bu kümelerin 1'i major, 2'si minör iken, 7 tanesi tekli üyedir.
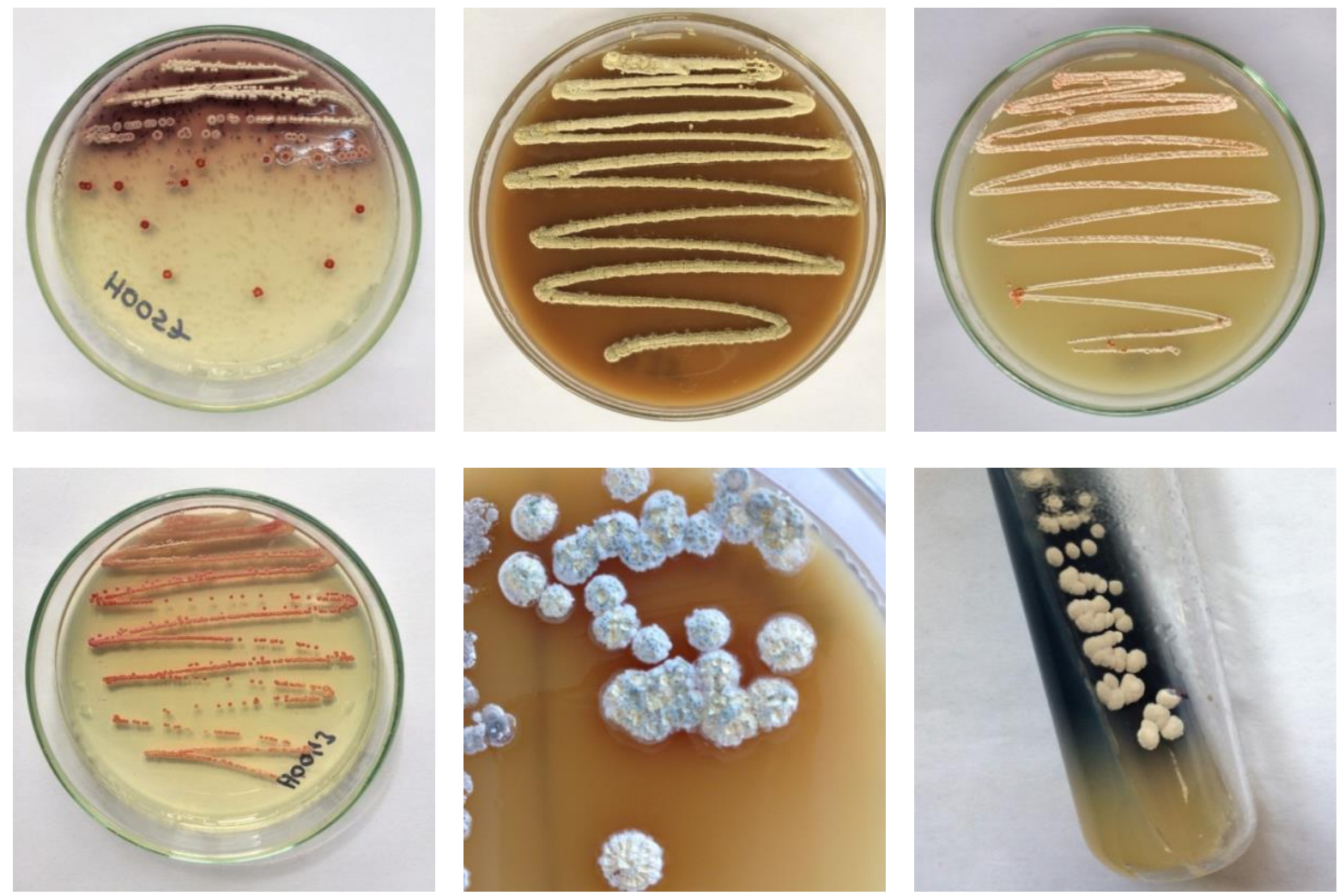

Şekil 1. Saflaştırma çalışmalarında Streptomyces suşlarının Medium 65 ve Bennet's Agar besi ortamlarında $27^{\circ} \mathrm{C}$ 'de 14 gün inkübasyon sonucu gelişen kolonileri
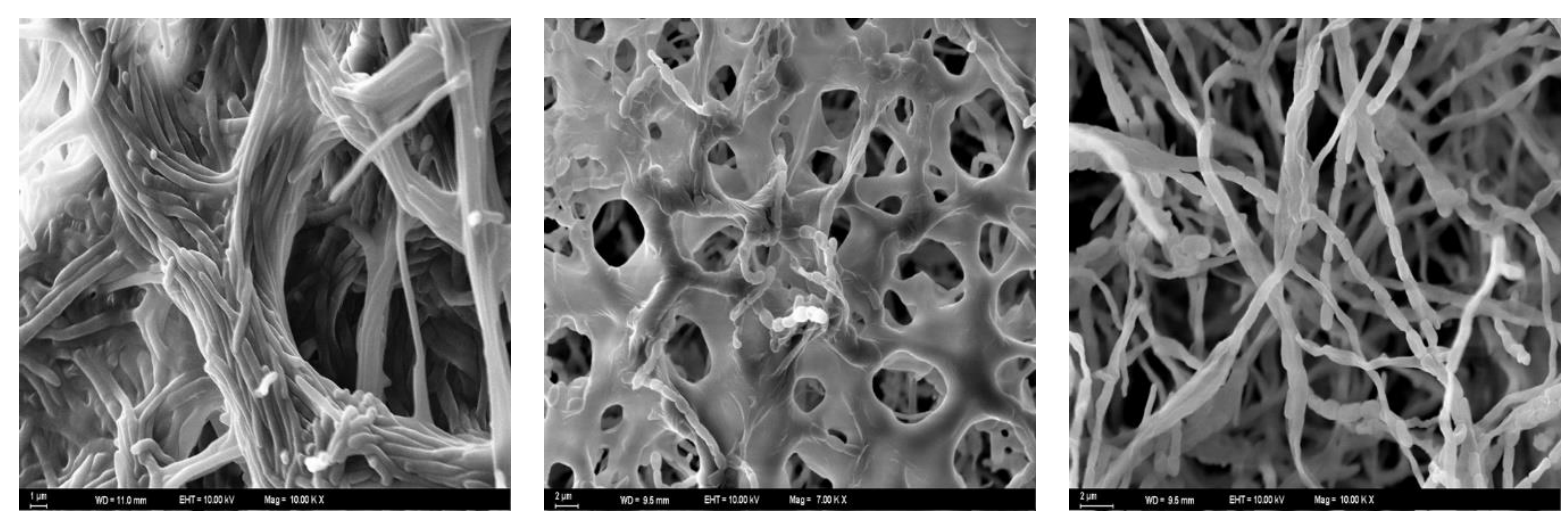

Şekil 2. Bazı Streptomyces türlerinin koloni gelişiminin taramalı elektron mikroskobu (SEM) ile görüntülenmesi 
UPGMA

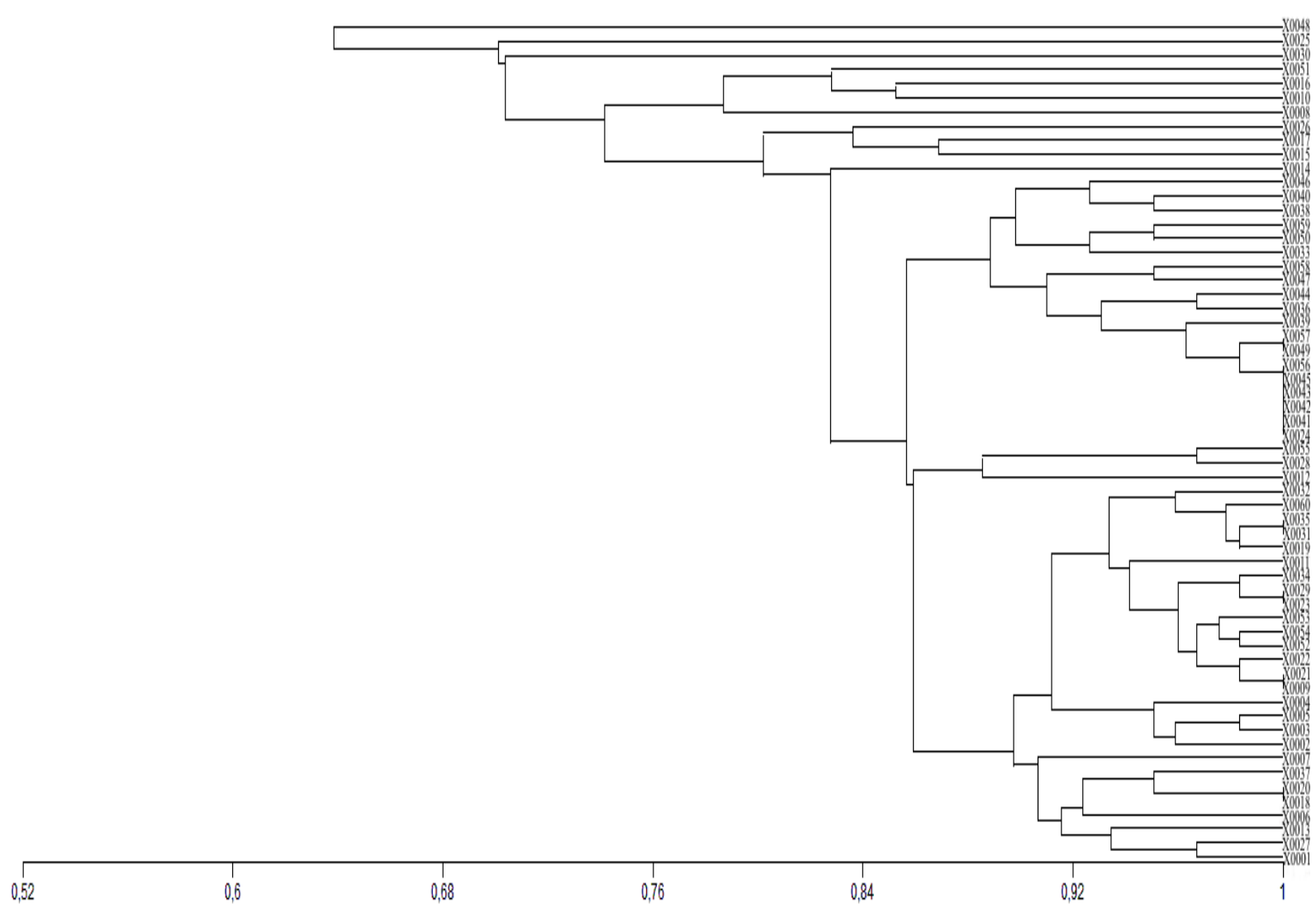

Şekil 3. 60 Streptomyces test izolatı için 61 farklı karakter bakımından uygulanan test sonuçlarının MVSP 3.2. (Multi Variate Statiscial Package) programı (SSM) Simple Matching Coefficient ile oluşturulan dendogram

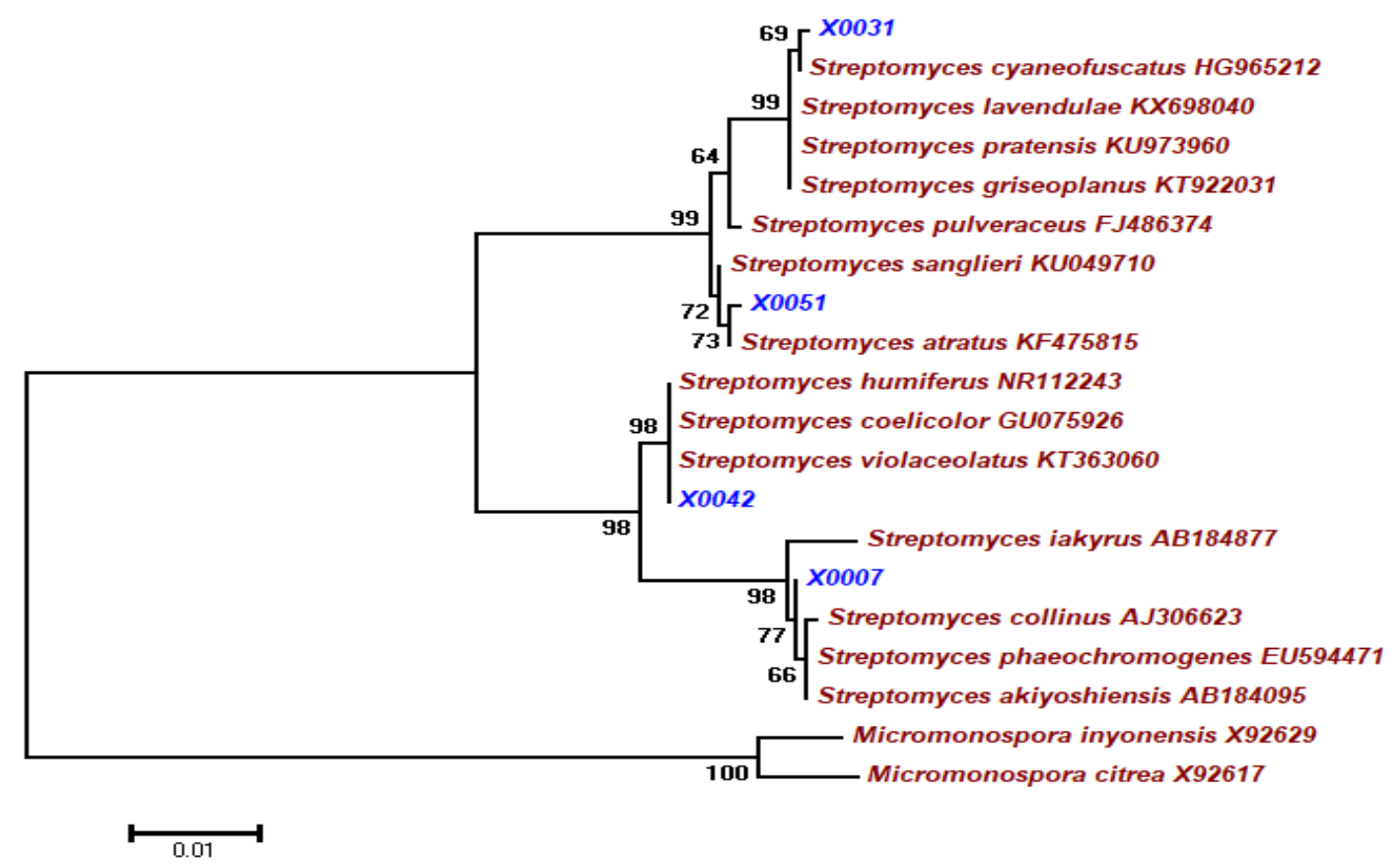

Şekil 4. Streptomyces izolatlarının 16S rDNA dizi analizi sonuçlarına göre Mega7 programı ile oluşturulan filogenetik dendogramı 
Streptomyces bakterileri genelde su ve toprağ içeren bütün ekosistem tiplerinde bulunurlar ancak toprak ortamını diğerlerine tercih ederler [24]. Özdemir ve arkadaşları tarafindan yapılan çalışmada toprakta izole edilen 139 Streptomyces suşu 39 renk grubuna ayrılmışırır [25]. Biz de çalışmamızda koloni sayım sonuçlarına göre göl içerisinden alınan toprak numunelerinde daha az Streptomyces bakterisine rastlamış olmamız literatürler ile paralellik göstermektedir.

Morfolojik tanıda önemli bir kriter olan renk tespitleri, olgunlaşmış ve spor vermiş kültürler üzerindeki havasal ve substrat miselyum rengine, difüziye pigment üretip üretmediğine, varsa rengine bakılarak yapılmaktadır. Renk tespitleri için kullanılan ortam literatürlerde belirtilmiş olan Oatmeal besi ortamıdır ve gözlemler 7, 14 ve 21. günlerde kuzeye bakan bir pencerede parlak gün 1şığında yapılmalıdır [9]. Bunlar göz önünde bulundurarak izole edilen 60 Streptomyces suşu 4 renk grubuna ayrıldı. Oluşan bu gruplar Atalan ve arkadaşları tarafindan bildirilen sonuçlarla paralellik gösterdi [26]. Streptomyces suşlarının yapılan testler doğrultusunda bilgisayar yardımıyla teşhisleri için IDENTAX Bacterial Identifier 1.2 programı kullanıldı. Bu program yardımıyla test suşlarının major taksonlar [11] için oluşturulan matrikse göre teşhisleri yapıldı. Bu matriks ile teşhis edilen suşların mevcut benzerlik matriksleri içerisinde en fazla benzerlik gösterdikleri tür en yakın takson olarak kabul edildi. Sonuçta toplam 60 Sreptomyces suşundan 20 tanesi mevcut taksonomik gruplarda yer alan türlerle \%85'in altında benzerlik gösterdi. Yapılan diğer çalışmalarla karşılaştırıldığında \%85'in altında benzerlik gösteren tür sayısının fazla olduğu belirlendi. Williams ve arkadaşları tarafından programa girilmesi önerilen veri sayısı en az 50 olmalıdır [19]. Teşhis matriksi mevcut Streptomyces türlerin verilerini tam içermediği için eksik kalmaktadır.

Nümerik analiz için uygulanan 61 test sonucunun tamamı MVSP 3.2 (Multi-Variate Statistical Package) programina 1/0 olarak girildi. UPGMA (Unweighted pair group method with arithmetic average) Cluster Analizi yapıldı ve $\mathrm{S}_{\mathrm{SM}}$ (simple macthing coefficient) benzerlikleri dendogramları oluşturuldu. Oluşturulan dendogramda $\mathrm{S}_{\mathrm{SM}}$ sonuçlarına göre $\% 85$ benzerlik oranı esas alındığında 2 minör, 1 major küme, 7 tane tekli üye oluştu. Major küme 49 izolat içerdi. Dendogramda aralarındaki benzerlik oranı \%100 olan türlerin çoğunlukla aynı lokalitelerden izole edildiği görüldü.

Streptomyces türlerini teşhis etmek için morfolojik özellikleri ve karbon kaynaklarını kullanma özelliklerine dayanan tanılama metotları günümüzde hala kullanılmakta olan ve geçerliliği olan metotlardır. Morfolojik ve fizyolojik metotlar ile tanı çalışmaları için kolonilerin çok iyi sporulasyon vermiş olması gerekir. Streptomyces türleri ise 15-20 gün hatta bazen daha fazla bir sürede spor verebilmektedirler. Kültürlerin spor zincirlerin şeklinin de gözlenmesi için kolonilerin tam sporulasyon vermiş olması gerekir. Ancak kültürlerin spor zincir morfolojilerinde zamanla değişiklikler olacağından dolayı fazla yaşlanmamış olması gerekir. Yani Streptomyces türlerinin morfolojik ve fizyolojik özelliklerine dayanılarak yapılan tanı çalışmaları hassasiyet, zaman ve emek ister. $\mathrm{Bu}$ nedenle Streptomyces türlerinin teşhisine yönelik çalışmalarda hız ve pratiklik kazanmak için moleküler metotlara başvurulur. Ayrıca güvenilirlik sorunu olmadığı için moleküler metotlar önemli bir yer almıştır. Moleküler metotlardan biri olan $16 \mathrm{~S}$ rDNA gen dizileme filogenetik akrabalığın değerlendirilmesinde ve bakterilerin taksonomik pozisyonlarının belirlenmesinde temeli oluşturan bir tekniktir [18].

Bu çalışmada, renk gruplarını temsilen seçilen X0007, X0031, X0042 ve X0051 izolatlarının $16 \mathrm{~S}$ rDNA gen bölgesi 27F ve 1492R primerleri ile çoğaltılmıştır. Bu gen bölgesinin sekans analizi sonuçları alınarak Codon Code Aligner V.6.0.2 programında tüm nükleotitler elektroferogramlara bakılarak tek tek kontrol edilmiştir. 16S rDNA gen dizileri NCBI'dan elde edilmiş ve izolatların gen dizileriyle birlikte hizalanmıştır. Bu çalışmada, türler arasındaki genetik uzaklığ 1 belirlemek için filogenetik analizlere uygun formatlara getirilmiş 16S rDNA dizileri, Maksimum Olabilirlik algoritması seçilerek Jukes ve Cantor'un uzaklık matrisi ile filogenik ağaçlar oluşturulmuştur.

X0007 izolatı için oluşturulan filogenetik ağaçta Streptomyces bakterileri güçlü bir homoloji ile kümelenmiştir. Dış grup olarak Micromonospora inyonensis ve Micromonospora citrea seçilmiştir. X0007 izolatına ait gen dizisi ve NCBI'dan alınan izolatların gen dizileri 16S rDNA gen bölgesi filogenetik analizinde; X0007 suşunun filogenetik konumunu belirlemek için 16S rDNA sekansı analizi yapıldı. Toplam 1314 nükleotidlik 16S rDNA geni belirlenmiştir. X0007 nolu izolatın karşılaştırılan 1314 nt'lik bölgesinde 11 nükleotit farklılı̆̆ ve \% 99,16 benzerlik oranıyla Streptomyces iakyrus AB184877 suşu ile sıkı bir homoloji ile kümelenmiştir.

X0031 izolatı için oluşturulan filogenetik ağaçta Streptomyces cyaneofuscatus HG965212, Streptomyces lavendulae KX698040, Streptomyces pratensis KU973960 ve Streptomyces griseoplanus 
KT922031 bakterileri genel olarak güçlü bir homoloji ile kümelenmiştir. X0031 izolatına ait gen dizisi ve NCBI'dan alınan izolatların gen dizileri 16S rDNA gen bölgesi filogenetik analizinde; X0031 suşunun filogenetik konumunu belirlemek için 16S rDNA sekansı analizi yapıldı. Toplam 1338 nükleotidlik 16S rDNA geni belirlenmiştir. X0031 nolu izolatın karşılaştırılan 1338 nt'lik bölgesinde 12 nükleotit farkl1lığ ve \% 99,25 benzerlik ile Streptomyces cyaneofuscatus HG965212 suşu ile sık1 bir homoloji ile kümelenmiştir.

X0042 izolatı için oluşturulan filogenetik ağaçta Streptomyces humiferus NR112243, Streptomyces coelicolor GU072956 ve Streptomyces violaceolatus KT363060 bakterileri güçlü bir homoloji ile kümelenmiştir. X0042 suşunun toplam 1372 nükleotidlik 16S rDNA geni belirlenmiştir. X0042 nolu izolatın 1372 nt'lik bölgesi karşılaştırılmış ve 3 baz farklılığ görülmüştür. X0042 izolatı \%99,78 oranıla Streptomyces violaceolatus KT363060 suşu ile benzerlik göstermiştir.

X0051 izolatı için oluşturulan filogenetik ağaçta Streptomyces pulveraceus FJ486374, Streptomyces sanglieri KU049710 ve Streptomyces atratus KF475815 bakterileri güçlü bir homoloji ile kümelenmiştir. X0051 nolu izolatın 1382 nükleotidlik bölgesi karşıllaştırılmış ve 4 baz farklılığ görülmüştür. X0042 izolat1 \%99,71 oranıla Streptomyces atratus KF475815 suşu ile benzerlik göstermiştir.

Tablo 1. Streptomyces izolatlarının filogenetik ve moleküler olarak benzerlik oranları

\begin{tabular}{lclll}
\hline NO & $\begin{array}{c}\text { Renk } \\
\text { Grubu }\end{array}$ & MVSP & IDENTAX & NCBI BLAST \\
\hline
\end{tabular}

\begin{tabular}{llll}
\hline X0007 1 & 3 & $\begin{array}{l}\text { Streptomyces } \\
\text { filipinensis }\end{array}$ & $\begin{array}{l}\text { Streptomyces iakyrus }(\% 99) \\
\text { Streptomyces collinus }(\% 99)\end{array}$ \\
& & Streptomyces phaeochromogenes (\%99) \\
& & Streptomyces akiyoshiensis $(\% 99)$
\end{tabular}

\begin{tabular}{llll}
\hline $\mathrm{X} 0031$ & 3 & Streptomyces cyaneus & Streptomyces cyaneofuscatus (\%99) \\
& & Streptomyces lavendulae $(\% 99)$ \\
& Streptomyces pratensis $(\% 99)$ \\
& Streptomyces griseoplanus $(\% 99)$
\end{tabular}

\begin{tabular}{llll}
\hline $\mathrm{X} 0042$ & 3 & Streptomyces cyaneus & $\begin{array}{l}\text { Streptomyces humiferus }(\% 99) \\
\text { Streptomyces coelicolor }(\% 99) \\
\end{array}$ \\
& & Streptomyces violaceolatus (\%99)
\end{tabular}

\begin{tabular}{llll}
\hline X0051 4 Tekli & Streptomyces purpureus & $\begin{array}{l}\text { Streptomyces pulveraceus }(\% 99) \\
\text { Streptomyces sanglieri }(\% 99) \\
\end{array}$ \\
& & Streptomyces atratus $(\% 99)$
\end{tabular}

\section{Sonuç ve Öneriler}

Sakarya ili sınırları içerisindeki Sapanca Gölü'nün 6 farklı lokalitesinden alınan toprak ve sediment örneklerinden 60 Streptomyces bakterisi izole edilmiştir. 60 Streptomyces suşlarının renk gruplandırması yapılarak ve 4 grup elde edilmiştir. Nümerik taksonomik çalışmalar için uygulanan 61 farklı fenotipik ve biyokimyasal test sonucunda suşların dendogramları oluşturularak klasik taksonoimk çalışmalar sonucu elde edilen verilen benzerlik dendogramı olarak sunulmuştur. İzole edilen 60 suşun IDENTAX programına göre teşhisleri yapılmış ve 47 izolat Streptomyces cyaneus olarak teşhis edilmiş olması tür çeşitliliği için ana habitatın toprak olduğu gerçeğini doğrulamaktadır. Moleküler karakterizasyon çalışmaları için renk gruplarını temsilen 4 suş seçilerek ve filogenetik konumlarını belirlemek için 16S rDNA sekansı analizleri yapılmış, dizi analizlerine göre tüm izolatlar Streptomyces 
cinsine dahil olduğu NCBI gen bankası verileri ile filogenetik ağaçları oluşturulmuştur. Çalışmamızda X0007, X0031, X0042 ve X0051 suşlarının yapılan moleküler teşhis ve fenotipik özelliklerinre dayalı bilgisayar yardımıyla teşhis sonuçlarının aynı olmadığı görüldü. IDENTAX teşhis programı ile yapılan teşhis çalışmalarının daha sağlıklı sonuçlar vermesi için literatürlerde belirtilen major kümeler ile birlikte minör kümeler için belirlenen teşhis matriksleri de kullanılmasının yanı sıra mutlaka moleküler analizlerle desteklenmesinin sonuçları daha doğru ortaya koyacağı açıktır.

\section{Teşekkür}

Bu çalışma Van Yüzüncü Y11 Üniversitesi Bilimsel Araştırma Projeleri tarafindan FYL-2016-5499 Nolu Proje ile Desteklenmiştir.

\section{Kaynaklar}

[1] Seipke R., Kaltenpoth M., Hutching, M., 2012. Streptomyces as symbionts: an emerging and widespread theme. FEMS Microbiology Reviews, 36 (4): 862-876.

[2] Bérdy J., 2005. Bioactive microbial metabolites. Journal of Antibiotics, 58: 1-26.

[3] Hopwood D., 2004. New Drugs by Manipulating Streptomyces genes. Microbiology Today, 34: 64-65.

[4] Goodfellow M., Erika Q., Katarzyna W., Pawel M., Abdalla O., Ahmed F., Mohamed H., Jolanta Z., 2007. Streptomyces sudanensis sp. nov., a new 76 pathogen isolated from patients with actinomycetoma. Antonie Van Leeuwenhoek., 22: 18157699.

[5] Chater KF., Losick R., 2001. Mycelial life style of Streptomyces coelicolor A3(2) and its relatives. In Bacteria as Multicellular Organisms (Edited by J.A. Shapiro, M. Dworkin). Oxford Univ. Press, Newyork. 149-82.

[6] Kutzner K.J. 1981. The family Streptomycetaceae. In: Starr MP, Stolp H, Tr_per HG, Balows A, Schlegel HG (eds) The prokaryotes, A Handbook on Habitats, Isolation, and Identification of Bacteria, vol. 2, Springer-Verlag, New York, 2028-2090.

[7] Williams S.T., Goodfellow M., Alderson,G., 1989. Genus Streptomyces Waksman and Henrici. In Bergey's Manual of Systematic Bacteriology, vol. 4 (edited by Williams, Sharpe, Holt). Williams \& Wilkins, Baltimore, pp: 2452-2492.

[8] Newman D.J., Cragg G.M., Snader K.M. 2003. Natural Products as sources of new drugs over the period 1981-2002. Journal of Natural Products, 66: 1022-1037.

[9] Shirling E.B., Gottlieb D. 1966. Methods for characterization of Streptomyces species. International Journal of Systematic Bacteriology, 16: 313-340.

[10] Szabo I.M., Marton M., Buti I., Fernandez C.A. 1975. Diagnostic key for the identification of species of Streptomyces and Streptoverticillium included in the International Streptomyces project. Acta Bot Acad Sci Hung., 21: 387-418.

[11] Holt J.G., Krieg N.R., Sneath P.H.A., Staley J.T., Williams S.T. 1994. Bergey's manual of determinative bacteriology. 9th ed. Baltimore: The Williams \& Wilkins Co.

[12] Nitsch, B., Kutzner H. J. 1969. Egg-yolk as a diagnostic medium for Streptomycetes. Experientia 25: $113-6$.

[13] Ausubel F.M., Brent R., Kingston R.E., Moore D.D., Seidman J.G., Smith J.A., Struhl K. 1994. Current protocols in molecular biology. John Wiley and Sons, New York. 2.0.1-2.14.8.

[14] Lane D.J. 1991. 16S/23S rRNA Sequencing. In: Stackebrandt, E. and Goodfellow, M., Eds., Nucleic Acid Techniques in Bacterial Systematic, John Wiley and Sons, New York, 115-175.

[15] Awla F.M., Ozdemir K., Ertas M., 2017. Irak-Erbil'den Alınan Baz1 Toprak Numunelerinden Streptomyces Bakterilerinin İzolasyonu, Ekstraselüler Hidrolitik Enzim Kabiliyetlerinin Belirlenmesi ve 16S rDNA Analizi. Yüzüncü Y1l Üniversitesi Fen Bilimleri Enstitüsü Dergisi/ Journal of the Institute of Natural \& Applied Sciences, 22 (2): 132-138.

[16] Williams S.T., Goodfellow M., Aldersons G., Wellington E.M.H., Sneath, P.H.A., Sackin M.J. 1983a. Numerical Classification of Streptomyces and Related Genera. Journal of General Microbiology, 129: 1743-1813. 
[17] Williams S.T., Goodfellow M., Wellington E.M.H., Vickers J.C., Aldersons G., Sneath P.H.A., Sackin M.J. Mortimer A.M. 1983b. A probability matrix for identification of some Streptomycetes. Journal of Genera Microbiology, 129: 1815-1830.

[18] Özdemir K. 2008. Lens orientalis (Boiss.) Hand \& Mazz ve Cicer anatolicum Alef. Rizosferinden Streptomyces türlerinin izolasyonu, teşhisi ve karakterizasyonu. Doktora Tezi, Yüzüncü Y1l Üniversitesi, Fen Bilimleri Enstitüsü, Van.

[19] Ausubel F.M., Brent R., Kingston R.E., Moore D.D., Seidman J., Smith G.J.A., Struhl K. 1994. In: Current Protocols in Molecular Biology, Wiley, New York, 2.1.1-2.1.3.

[20] Kim B., Sahin N., Minnikin D.E., Zakrzewska-Czerwinska J., Mordarski M., Goodfellow M. 1999. Classification of thermophilic Streptomyces, including the description of Streptomyces thermoalkalitolerans sp. nov. International Journal of systematic Bacteriology, 49: 7-17.

[21] Rintala H., Nevalainen A., Ro“nka E., Suutar M. 2001. PCR primers targeting the 16S rRNA gene for the specific detection of streptomycetes. Molecular and Cellular Probes, 15: 337-347.

[22] Lanoot B, Vancanneyt M., Bart H., Vandemeulebroecke K. 2005. Grouping of Streptomycetes using 16S-ITS RFLP fingerprinting. Research in Microbiology, 156: 755-762.

[23] Sembiring L., Goodfellow M. 2008. Ecological approach to unravel Streptomycete diversity as an unsurpassed sources of natural bioactive products. Microbiology Indonesia, 2 (2): 49-56.

[24] Atalan E., Manfio G.P., Ward A.C., Kroppenstedt R.M., Goodfellow M. 2000. Biosystematic studied on novel Streptomycetes from soil. Antonie van Leeuwenhoek, 77: 337-353.

[25] Ozdemir K., Ogun E., Ertas M., Acar S., Atalan E. 2014. Identification of biodiversity of some Streptomyces species and determination of a restriction fragment length polymorphism (RFLP) profile of 16S rDNA gene region. Journal of Animal and Veterinary Advances, 13 (16): 978-988

[26] Langham C.D., Williams S.T., Sneath P.H.A., Mortimer A.M. 1989. New probability matrices for identification of Streptomyces. Journal of General Microbiology, 135: 121-133. 